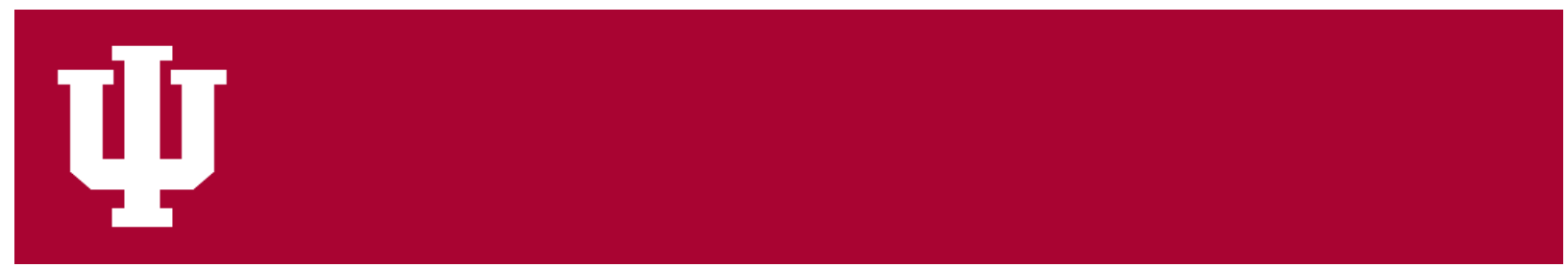

IUScholarWorks at Indiana University South Bend

\title{
Motherless Tongues: The Insurgency of Language amid Wars of Translation/Ethnology and Empire: Language, Literature, and the Making of the North American Borderlands
}

Mattox, Jake

To cite this article: Mattox, Jake. "Motherless Tongues: The Insurgency of Language amid Wars of Translation/Ethnology and Empire: Language, Literature, and the Making of the North American Borderlands." American Literature, vol. 90, no. 1, 2018, pp. 171-73, doi:10.1215/00029831-4326466.

This document has been made available through IUScholarWorks repository, a service of the Indiana University Libraries. Copyrights on documents in IUScholarWorks are held by their respective rights holder(s). Contact iusw@indiana.edu for more information. 


\section{Book Reviews}

Motherless Tongues: The Insurgency of Language amid Wars of Translation. By Vicente L. Rafael. Durham, NC: Duke Univ. Press. 2016. xii, 255 pp. Cloth, \$89.95; paper, \$24.95; e-book available.

\section{Ethnology and Empire: Languages, Literature, and the Making of the North American Borderlands. By Robert Lawrence Gunn. New York: New York Univ. Press. 2015. xiii, 241 pp. Cloth, \$89.00; paper, \$28.00; e-book available.}

These texts explore the functions of language in colonial and postcolonial settings, particularly its usages, structures, forms, and circulation, as well as theories about it. Their approaches, though, are significantly different. Vicente L. Rafael, focusing on histories and texts of the revolutionary and postrevolutionary contexts in the Philippines and in recent US occupations in Iraq and Afghanistan, pursues scenarios in which language resists the full and stable meanings that might be intended in service of or in opposition to the colonizing project. As he suggests in an interview reprinted as the final piece in his collection, we should "think of language as a historical agent that . . exceeds human control” (190). Robert Lawrence Gunn, on the other hand, is interested in how the "misrecognition" of differing forms of language in the antebellum US context occluded Native American resistance and agency while also supporting the practices and discourses of westward expansion.

Both works draw from and contribute to the important subfield in interdisciplinary American studies that explores the contexts and cultures of US expansionism as initiated in, for instance, works such as Amy Kaplan and Donald Pease's Cultures of United States Imperialism (1993), to which Rafael contributed an essay. For Rafael, translation and language are always the sites and stakes of colonial oppression and of nationalist resistance, violence, and play. Gunn's work traces the development of ethnological linguistics as a

American Literature, Volume 90, Number 1, March 2018

DOI $10.1215 / 00029831-4326466$ C 2018 by Duke University Press 
literal and representational appendage of expansionist policies and practices even as he considers the "manners of speaking (signed, embodied, written, oral, and through signifying objects) of Native peoples" in order to "highlight a linguistic network of intertribal pathways through which acts of Native American resistance might be reimagined" (11). Both texts also draw on the work of Michel Foucault and others to build an analysis of expansionist enterprises as both representational and material and that do not project from one center of power or one coherent ideology.

The chapters of Ethnology and Empire pursue the "interlocking institutional and literary histories of ethnology in the United States" (15) as framed in various "scenarios of troubled linguistic exchange" (3). This well-historicized analysis uses methods from linguistic theory and borderlands studies that seek to uncover previously occluded voices. Gunn's main textual sources include John Russell Bartlett's Personal Narrative of Explorations and Incidents in Texas, New Mexico, California, Sonora, and Chihuahua (1854), Black Hawk's Life (1833), John Dunn Hunter's Memoirs of a Captivity among the Indians of North America (1823), James Fenimore Cooper's The Last of the Mohicans (1826) and The Pioneers (1823), and Sarah Winnemucca's Life among the Piutes (1883). Deeply researched, the book also contains such sources as personal letters, reports to the American Philosophical Society, and lesser-known full-length texts.

One strength is how Gunn historicizes approaches in comparative linguistics that sought to correlate race and language. He contrasts amateur ethnologists with institutionalized "scientific" racists of the antebellum period, each of whom had different investments in the (misguided) promise of comparing the deeper grammatical foundations within languages to draw conclusions about Native American origins and, more broadly, racial kinship and difference. "Philologies of race" (17) is Gunn's apt term for this project, of which he finds suggestive traces in Cooper's fiction. Central to the philological project was the "misrecognition" of Plains Indian Sign Language and other forms of "manual linguistic discourse" (84), often denigrated as simply a necessary supplement to the incomplete spoken expression of the uncivilized. In the book's richest chapter, Gunn reads Hunter's captivity narrative, which includes an account of Tecumseh's speech to the Osages in the winter of 1811-12. Hunter both emphasizes the primary role of physical gesture in the speech and the impossibility of fully conveying its meaning. Gunn takes Hunter's text seriously, arguing that "Tecumseh's use of gesture contained signed linguistic components" that were "misclassified as sublinguistic in the antebellum period" (103), which bolstered claims that there was no linguistic basis meriting political recognition for Tecumseh's attempted pan-Indian alliance.

If Gunn is interested in ways that different forms of discourse have been misunderstood, often for political ends, Rafael pursues the significance of translation as a literal practice and a trope covering many practices and scenarios. The collected pieces in Motherless Tongues come from a talk, an 
interview, and several previously published essays from 1999 to 2015, plus a new introductory essay. Rafael's attention to language and the "wars of translation" centers on the concept of aporia (borrowed from Sarah Kofman) — a site within language that "prevents passage, blocks progress, and arrests movement from one place to another" (12). It is these aporias that Rafael's essays largely seek and explore, for they contain possibilities for play, joy, and insurgency. In them are located the "responses of . . . colonized peoples, working classes, and other subordinated groups ... who ... had been enmeshed in the language of colonizing power even as they wove their own traps to reverse and displace this power's hold" (14). For instance, Rafael reads nostalgic accounts of the revolution from leaders such as Santiago Alvarez and Emilio Aguinaldo and a popular song in Tagalog; in these varied sources, the sovereignty of the people is not enacted in traditional legalistic senses but through their daily and public expressions of joy, their singing, and their compassion for each other. Rafael finds another aporetic site in the postwar colonial schooling system wherein "Filipinized English," or the "vernacular shaping [of] the materiality of foreign words" (55), in addition to the "street" use of Tagalog slang, resisted the totalizing influence of the colonizer's tongue.

Other chapters consider the United States in Iraq and Afghanistan, offering many fascinating observations on translation, empire, the defense of monolingualism in the United States, and the role of translators in the occupation of Iraq. For example, Rafael considers the discourses emanating from the Defense Language Institute Foreign Language Center and its focus on the "language-enabled solider" (124), and he reads The U.S. Army/Marine Corps Counterinsurgency Field Manual from 2006 and its detailed protocol for using translators, ultimately drawing on Walter Benjamin to argue that translation "convey[s] a semantic excess that remains impervious to narrative domestication" (144). Additional chapters offer reflections on the connections among theory, methodology, and the personal identities and histories of influential scholars Arjun Appadurai, Benedict Anderson, Renato Rosaldo, Reynaldo Ileto, and (in the introduction) Rafael himself.

While Rafael's concept of "translation" can sometimes seem a bit capaciously applied, thus losing some critical edge, both texts do an excellent job of exploring the ways that everyday practices, uses of language, and scenes of translation are where we might locate and further theorize persistent expressions of identity formation, anticolonial practices, and resistance. The stakes are high; listening to such expressions, Rafael argues, "might help us, whoever we are, find ... some way out of the aporetic violence, the endless wars, and the tortured lives of this common imperial moment” (18).

Jake Mattox is chair and associate professor of US literature in the Department of English at Indiana University, South Bend. His work focuses on nineteenth-century literatures of US expansionism and critical pedagogy. 